\title{
The role of PAX9 promoter gene polymorphisms in causing hypodontia: a study in the Jordanian population
}

This article was published in the following Dove Press journal:

The Application of Clinical Genetics

\section{Ahmed Abu-Siniyeh' \\ Omar F Khabour ${ }^{1}$ \\ Arwa I Owais ${ }^{2}$}

'Department of Medical Laboratory Sciences, Faculty of Applied Medical

Sciences, Jordan University of Science and Technology, Irbid, Jordan; ${ }^{2}$ Department of Applied Dental Sciences, Faculty of Applied Medical Sciences, Jordan University of Science and Technology, Irbid, Jordan
Correspondence: Omar F. Khabour Department of Medical Laboratory Sciences, Jordan University of Science and Technology, Irbid 22 I I0, Jordan

Tel +962797855269

Email khabour@just.edu.jo
Background: The congenital absence of one or few teeth, hypodontia, is considered one of the utmost dental ageneses in human beings. Several genes have been shown to be involved in the development of hypodontia such as paired box gene 9 (PAX9). The expression of PAX9 is controlled by several polymorphic elements in the promoter region of the gene on $14 \mathrm{q} 13.3$ locus. The aim of this study was to find any association between $P A X 9$ c.-912T $>\mathrm{C}$ (rs2073247) and c. $-1031 \mathrm{G}>$ A (rs2073244) promoter polymorphisms and the development of hypodontia among the Jordanian population.

Methods: Genotyping of the polymorphisms in 72 unrelated subjects with hypodontia was performed using PCR-restriction fragment length polymorphism (RFLP) technique and compared with that of 72 normal healthy unrelated control individuals.

Results: The hypodontia group had a significantly higher $-1031 \mathrm{GG}$ genotype $(P<0.01)$ and a significantly lower $-912 \mathrm{TC}$ genotype $(P<0.01)$ compared with the control group. The results suggest that the transcriptional activity of $P A X 9$ gene is affected by polymorphisms in the promoter region of this gene and is associated with hypodontia phenotype.

Conclusion: The rs2073247) and rs2073244 promoter polymorphisms of PAX9 might play a role in the development of hypodontia in the Jordanian population.

Keywords: $P A X 9$, hypodontia, Jordan, polymorphism, promoter

\section{Introduction}

Hypodontia, the congenital absence of less than six permanent teeth, is one of the most prevalent craniofacial congenital malformations in human beings, ${ }^{1}$ with an overall incidence of $2.0 \%-10.0 \%$, depending on the population studied excluding the absence of third molars. ${ }^{2}$ Hypodontia is common for the lower second premolars and the upper lateral incisors. ${ }^{3,4}$ Hypodontia can occur as a result of both environmental and genetic factors. For example, trauma of the dental region, chemotherapy, or radiotherapy has been shown to be associated with hypodontia. Genetic factors such as variations in MSX1 and paired box gene 9 ( $P A X 9$ ) have also been shown to be related to non-syndromic hypodontia. ${ }^{5,6}$

The $P A X 9$ gene is a member of the paired box (PAX) family of transcriptional factors. The gene is localized on the long arm of chromosome 14 (14q21) and has been shown to play an important role in dental development especially in the bud stage. ${ }^{3,7,8}$ Mutations in $P A X 9$ gene have been shown to cause familial tooth agenesis. ${ }^{9-12}$ Moreover, several polymorphisms in $P A X 9$ gene have been shown to increase the risk factor for the development of hypodontia. The c.-1031G $>$ A and c.-912T $>$ C single-nucleotide polymorphisms (SNPs) in $P A X 9$ gene have been shown to be associated with hypodontia in 
the Caucasian population. ${ }^{13}$ Similarly, Bianchi et $\mathrm{al}^{14}$ showed that the $\mathrm{C}$ allele of c.-915G $>\mathrm{C} \mathrm{SNP}$ of $P A X 9$ gene is related to hypodontia. Therefore, polymorphic variants of $P A X 9$ gene in addition to mutations might be a risk factor for tooth agenesis.

This study aimed to investigate the association between PAX9 c.-1031G >A and c.-912T >C promoter polymorphisms and the development of hypodontia among the Jordanian population.

\section{Subjects and methods}

In this study, 72 unrelated healthy subjects diagnosed with non-syndromic hypodontia and a similar number of healthy controls of unrelated individuals with the same mean age of 20 years were enrolled.

Sample collection was done in the Dental Teaching Center, Jordan University of Science and Technology (JUST), Jordan. Approval from the institutional review board (IRB) at the university was obtained. Both the IRB at JUST committees utilized the ethical standards as laid down in the 1964 Declaration of Helsinki and its later amendments. The procedures and possible discomforts, risks, and benefits were explained to the patients involved, and their written informed consents were obtained.

The selection criteria were as follows: healthy, unrelated individuals with agenesis of one to five permanent teeth, excluding third molars, and the lack of any other craniofacial malformations. Control subjects were all healthy, unrelated, and had normal primary and permanent dentition and did not show any craniofacial abnormalities. The diagnosis was confirmed by the same dentist after obtaining thorough history and making orthopantomographs for all subjects.

The DNA for the genotyping of examined SNPs was isolated from the blood collected in EDTA sterile tubes using DNA extraction kit obtained from Promega Corporation (Fitchburg, WI, USA) according to the manufacturer's instructions. DNA concentration and quality were assessed spectrophotometrically, and DNA was stored at $-20^{\circ} \mathrm{C}$ until used.

Polymorphisms of $P A X 9$ c. $-1031 \mathrm{G}>\mathrm{A}$ and c.-912T $>\mathrm{C}$ were typed by restriction fragment length polymorphism (RFLP) according to the criteria specified by Peres et $\mathrm{al}^{13}$ using HaeIII and $\mathrm{MseI}$ restriction enzymes (Fermentas, Glen Burnie, MD, USA) respectively. For both polymorphisms, the used primers were as follows: forward: 5'-AGC CTG AAT CCT GTG TGC AC-3' and reverse: 5'-CTA ATC TAA AGT GTA CCG TAT GC-3'. Amplification was performed in PCR tubes containing $100 \mathrm{ng}$ of DNA, $1 \mu \mathrm{M}$ of each primer and ready-to-use PCR master mix obtained from Promega Corporation. An Eppendorf thermocycler (Eppendorf, Hamburg, Germany) were used, and the cycling conditions were as follows: $95^{\circ} \mathrm{C}$ for 5 minutes and 35 cycles at $95^{\circ} \mathrm{C}$ for 60 seconds, $58^{\circ} \mathrm{C}$ for 30 seconds, and $72^{\circ} \mathrm{C}$ for 60 seconds, followed by a final extension of 5 minutes at $72^{\circ} \mathrm{C}$. The amplified fragment (202 bp) was detected using $2 \%$ agarose gel electrophoresis prior to restriction digestion, which was carried out for each polymorphism separately in 20 $\mu \mathrm{L}$ final volume reaction using $10 \mu \mathrm{L}$ of PCR product and 1 unit of HaeIII for c.-1031G >A or 2.0 units of MseI for c.-912T>C. The reactions were incubated at $37^{\circ} \mathrm{C}$ for 5 hours. Amplified fragment for $-1031 \mathrm{G}$ and $-912 \mathrm{~T}$ alleles stayed uncut, whereas the $-1031 \mathrm{~A}$ allele cut with HaeIII to give $176 \mathrm{bp}$ and $26 \mathrm{bp}$ fragments (Figure 1), and $-912 \mathrm{C}$ allele cut with MseI to give $144 \mathrm{bp}$ and $58 \mathrm{bp}$ fragments (Figure 2).

Hardy-Weinberg equation was used to test whether the examined SNPs were in equilibrium. The SPSS (version 21; IBM Corporation, Armonk, NY, USA) program was used for all statistical evaluations. $P$-value of $<0.05$ was considered significant.

\section{Results}

Male-to-female ratio was 1:1.18 in the hypodontia group and 1:1.25 in the control group ( $P>0.05$; Table 1$)$. About $16.7 \%$ of hypodontia subjects had three or more missing teeth, while

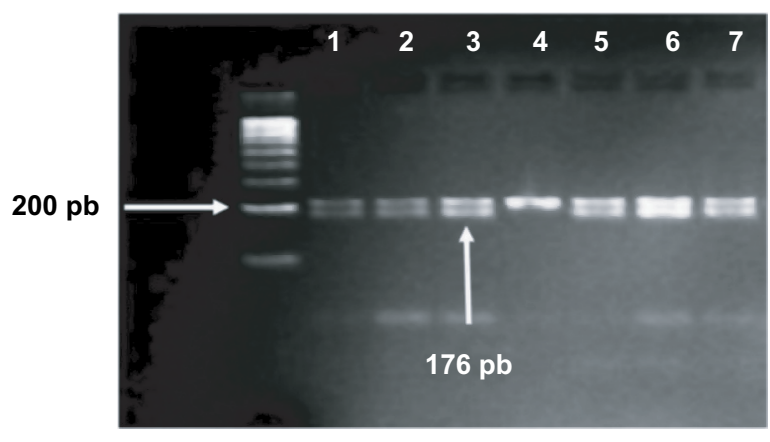

Figure I Gel electrophoresis of c.- I03 IG>A polymorphism.

Notes: PCR fragments (202 bp) were restricted with Haell enzyme. Samples in lanes I-3 and 5-7 represents heterozygous GA genotype. Sample in lane 4 represents homozygous AA genotype.

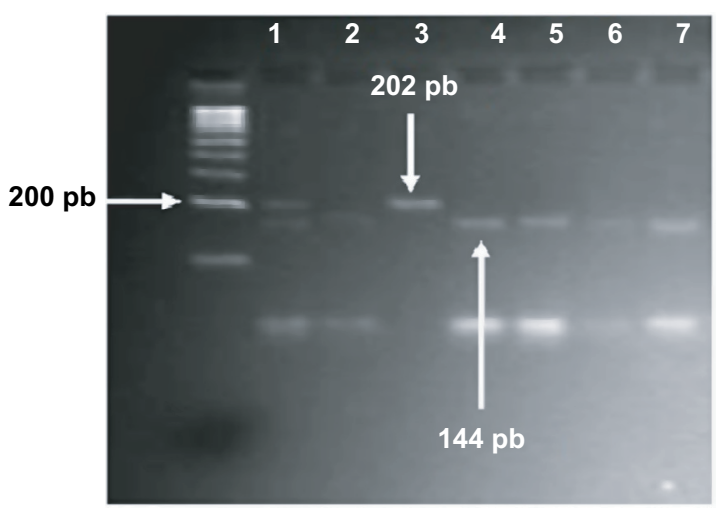

Figure 2 Gel electrophoresis of c.-9|2T>C polymorphism.

Notes: PCR fragments (202bp) were restricted with Msel enzyme. Sample in lane I represents heterozygous CT genotype. Samples in lane 2, 4-7 represent homozygous TT genotype. Sample in lane 3 represents CC genotype. 
Table I Aspects of population studied

\begin{tabular}{|l|l|}
\hline Family characteristics & N (\%) \\
\hline Gender & \\
Male & $33(45.8)$ \\
Female & $39(54.2)$ \\
Average age (years) & 20.88 \\
Number of teeth missing & \\
I & $28(38.9)$ \\
2 & $32(44.4)$ \\
3 or more & $12(16.7)$ \\
Type of teeth more often missing & \\
(total teeth missing =164) & \\
Central incisor & $30(18.3)$ \\
Lateral incisor & $74(45.1)$ \\
Canines & $10(6.1)$ \\
First premolar & $4(2.4)$ \\
Second premolar & $36(22)$ \\
First molar & $4(2.4)$ \\
Second molar & $6(3.7)$ \\
\hline
\end{tabular}

the percentage of subjects with one and two missing teeth was $83.3 \%$ (Table 1). The most prevalent missing teeth in the sample were incisors and the premolars (Table 1).

Table 2 summarizes the genotype distributions and allele frequencies of c.-1031G $>$ A PAX9 SNPs in different groups. Significant differences in the distribution of genotypes of the c.-1031G >A SNPs were detected (Fisher's exact test, $P<0.001$ ) with the GG homozygous genotype being more frequent among hypodontia subjects. Accordingly, the distribution of $\mathrm{G}$ allele to A allele was different between hypodontia subjects and controls (chi-squared test, $P<0.001)$. Therefore, the presence of the $-1031 \mathrm{GG}$ homozygous genotype increases the risk of hypodontia in the studied population.

The distribution of genotypes and the frequencies of alleles at PAX9 c.-912T $>$ C promoter SNPs in the two groups are summarized in Table 3. Similar to c.$1031 \mathrm{G}>$ A SNPs, the distribution of $P A X 9$ c. $-912 \mathrm{~T}>\mathrm{C}$ SNP genotypes (Fisher's exact test, $P<0.001$ ) and $\mathrm{T}$ to $\mathrm{C}$ allele (chi-squared test, $P<0.001$ ) was significantly different between the hypodontia group and the control group. Among the hypodontia group, only one subject $(<1 \%$ of the sample) was CT heterozygous compared with 24 subjects (33\% of the sample) in the control group. Therefore, the presence of the -912TC heterozygous genotype might be associated with low risk of hypodontia in the Jordanian population.

\section{Discussion}

In this study, we found that $P A X 9$ c. $-1031 \mathrm{G}>\mathrm{A}$ and c.-912T $>\mathrm{C}$ gene promoter polymorphisms were strongly associated with the development of non-syndromic hypodontia in the
Table 2 Genotype and allele frequencies of PAX c.- I03।G>A polymorphism in the Jordanian population

\begin{tabular}{|l|l|l|l|l|l|}
\hline & \multicolumn{2}{l|}{$\begin{array}{l}\text { Control } \\
\text { subjects }\end{array}$} & \multicolumn{2}{l|}{$\begin{array}{l}\text { Hypodontia } \\
\text { subjects }\end{array}$} & \multirow{2}{*}{-value } \\
\cline { 2 - 5 } & $\mathbf{n}$ & $\%$ & $\mathbf{n}$ & $\%$ & \\
\hline AA & 43 & 59.7 & 27 & 37.5 & \multirow{2}{*}{$<0.00 \mathrm{I}^{\mathrm{a}}$} \\
GA & 28 & 38.9 & 35 & 48.6 & \\
GG & $\mathrm{I}$ & 1.4 & 10 & 13.9 & \\
Allele A & $\mathrm{II}$ & 79.2 & 89 & 61.8 & \\
Allele G & 30 & 20.8 & 55 & 38.2 & \\
\hline
\end{tabular}

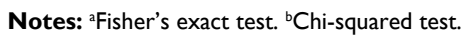

Table 3 Genotype and allele frequencies of PAX9 c.-9|2T>C polymorphism in the Jordanian population

\begin{tabular}{|l|l|l|l|l|l|}
\hline \multirow{2}{*}{} & \multicolumn{2}{l|}{$\begin{array}{l}\text { Control } \\
\text { subjects }\end{array}$} & \multicolumn{2}{l|}{$\begin{array}{l}\text { Hypodontia } \\
\text { subjects }\end{array}$} & \multirow{2}{*}{-value } \\
\cline { 2 - 5 } & $\mathbf{n}$ & $\%$ & $\mathbf{n}$ & $\%$ & \\
\hline CC & 3 & 4.2 & 3 & 4.2 & $<0.0 \mathrm{I}^{\mathrm{a}}$ \\
CT & 24 & 33.3 & $\mathrm{I}$ & $\mathrm{I} .4$ & \\
TT & 45 & 62.5 & 68 & 94.4 & \\
Allele C & 30 & 20.8 & 7 & 4.9 & $<0.0 \mathrm{I}^{\mathrm{b}}$ \\
Allele T & $\mathrm{II} 4$ & 79.2 & $\mathrm{I} 37$ & $95 . \mathrm{I}$ & \\
\hline
\end{tabular}

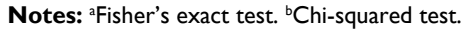

Jordanian population. The results showed that the presence of the $-1031 \mathrm{GG}$ and $-912 \mathrm{TC}$ genotypes might be associated with hypodontia in the Jordanian population.

The role of $P A X 9$ in tooth development is well established. $P A X 9$ is a member of gene family that encodes for transcriptional factors which is important during embryogenesis. ${ }^{15,16}$ PAX9 plays a significant role during odontogenesis in the progressive and reciprocal signal transduction pathways that normally occur in epithelial-mesenchymal cells. ${ }^{6}$ The gene product of $P A X 9$ appears early in the mesenchyme before ectodermal thickening and reaches its higher expression level during the initiation of bud and cap stages. ${ }^{17}$ In the dental mesenchyme, PAX9 protein interacts with MSX1 homeoprotein to regulate BMP4, which has an implication in downstream signaling cascade that is essential for enamel knot formation. ${ }^{16,18,19}$ Therefore, proper regulation of PAX9 signaling pathway is essential for odontogenic potential of mesenchyme and normal tooth development.

The results of this study agree with the finding in the Caucasian population (12). About $13.8 \%$ of hypodontia patients had GG genotype at -1031 position, while it was present in one subject from the control group (1.4\%). Similar finding was reported in the Caucasian population in Brazil where the GG genotype at $-1031(9.8 \%)$ in hypodontia subjects compared with $2.9 \%$ in controls. ${ }^{13}$ Regarding the c. $-912 \mathrm{~T}>\mathrm{C}$ polymorphism, the frequency of the TT genotype was $94.4 \%$ in the hypodontia group compared with $62.5 \%$ in the control 
Table 4 Mutations and polymorphisms in PAX9 gene that has been shown to cause tooth agenesis

\begin{tabular}{|c|c|c|c|}
\hline $\begin{array}{l}\text { Mutation/ } \\
\text { polymorphism }\end{array}$ & $\begin{array}{l}\text { Type of } \\
\text { mutation }\end{array}$ & $\begin{array}{l}\text { Amino acid } \\
\text { change }\end{array}$ & Reference \\
\hline $219 \operatorname{lns} G$ & Frame shift & G73fs $\times 316$ & 12 \\
\hline c. $340 \mathrm{~A}>\mathrm{T}$ & Nonsense & $\mathrm{KII} 4 \mathrm{X}$ & 29 \\
\hline c.793insC & Frame shift & $A 264 f s \times 315$ & 22 \\
\hline Deletion of gene & Del & L2IP & 10 \\
\hline c. $62 \mathrm{~T}>\mathrm{C}$ & Missense & R26W & 9 \\
\hline c.76C>T & Missense & G5IS & 26 \\
\hline c. $15 \mid \mathrm{G}>\mathrm{A}$ & Missense & A58fs $X 177$ & 21 \\
\hline c. $176 \mathrm{ins} 288 \mathrm{nt}$ & Frame shift & K9IE & 9 \\
\hline c. $27 \mid A>G$ & Missense & R28P & 9 \\
\hline$c .83 G>C$ & Missense & $\left|37 f_{s} X 4\right|$ & 23 \\
\hline c. I09insG & Frame shift & R47W & 27 \\
\hline c. $139 \mathrm{C}>\mathrm{T}$ & Missense & G73fs $X 316$ & 27 \\
\hline c. 219 insG & Frame shift & MIV & 27 \\
\hline c. $\mid A>G$ & Missense & $187 \mathrm{~F}$ & 24 \\
\hline c. $259 \mathrm{~A}>\mathrm{T}$ & Missense & $1207 f \mathrm{fs} X 21 \mathrm{I}$ & 16 \\
\hline c.619-62 I delATCins24nt & Frame shift & Q145X & 21 \\
\hline c. $433 \mathrm{C}>\mathrm{T}$ & Nonsense & R59X & 28 \\
\hline c. $175 \mathrm{C}>\mathrm{T}$ & Nonsense & & 30 \\
\hline c. $-915 \mathrm{G}>\mathrm{C}$ & SNP & & 14 \\
\hline c. $-9|2 T>C c .-103| G>A$ & SNPSNP & & 13,20 , this study \\
\hline
\end{tabular}

group. In the Caucasian population, Peres et $\mathrm{al}^{13}$ showed that TT genotype was strongly associated with hypodontia. In their study, TT genotype was $12.7 \%$ in hypodontia subjects compared with $2.8 \%$ in controls. However, in the present study, the frequency of the T/C genotype was higher in the control group (33.3\%) compared with the hypodontia subjects (1.4\%) which indicated that the T/C genotype was associated with low risk of hypodontia. In contrast, Peres et $\mathrm{al}^{13}$ reported similar frequencies of the T/C genotype in hypodontia individuals and the control group. On the other hand, a study from Turkey showed that AC haplotype of c.-1031G $>$ A and c. -912 T $>$ C SNPs carries less risk in having hypodontia. ${ }^{20}$ The discrepancy between the different studies could be due to variations in the genetic background and in the frequency of the $\mathrm{T} / \mathrm{C}$ alleles in the different populations. Despite such disparity, results of the current study and those of the study by Peres et al, ${ }^{13}$ provide strong evidence for the involvement of the $P A X 9$ c.-912T $>$ C promoter polymorphism in causing hypodontia phenotype in the two populations. In addition, the association between gene polymorphisms and hypodontia might have population specificity being affected by certain environmental factors or/and population genetic background.

Several mutations and polymorphisms in $P A X 9$ gene were reported to cause hypodontia in other populations (Table 4). For example, the deletion of the $P A X 9$ gene in American and Polish families was described to cause autosomal dominant agenesis which involves several primary and permanent molars. ${ }^{10,21}$ In the American population, frame shift mutations in exon 2 of $P A X 9$ were reported in individuals suffer from hypodontia. ${ }^{9,22}$ In addition, missense mutations in $P A X 9$ gene were also reported to cause hypodontia in several populations. ${ }^{4,9,11,16,21,23-27}$ Furthermore, nonsense mutations in $P A X 9$ that produce truncated proteins were identified to cause familial hypodontia and oligodontia phenotypes in subjects from Denmark, Finland, Spain, and USA. ${ }^{22,28-30}$ In the Caucasian population in Brazil, the G-915C SNP in the promoter region of $P A X 9$ gene was found to be associated with hypodontia. ${ }^{14}$ Mitsui et al ${ }^{31}$ reported two novel mutations (c.73_75delATC and c.146C >T) in the paired domain of PAX9 in patients with non-syndromic tooth agenesis from Japan. In a study from Saudi Arabia, a new mutation p.N40I in PAX9 was detected in two patients with non-syndromic tooth agenesis. ${ }^{32}$ A new initiation codon mutation (changes the ATG initiation codon to AGG) related to oligodontia was identified in the Chinese population. ${ }^{33}$ Thus, the abovementioned literature indicates a significant role for $P A X 9$ in tooth development in human beings.

\section{Conclusion}

Findings of this study indicated that c.-1031G $>$ A and c.912T $>$ C promoter polymorphisms in $P A X 9$ gene might be associated with hypodontia in the Jordanian population. The analysis of genes that involved in the development of hypodontia is important for understanding the genetic basis of hypodontia and might help in the management of this condition. 


\section{Acknowledgments}

The study was funded by Deanship of Research, JUST. The authors thank Mr Ahmad Abu-Wardeh for his technical help in the study.

\section{Disclosure}

The authors report no conflicts of interest in this work.

\section{References}

1. Arte S, Nieminen P, Pirinen S, Thesleff I, Peltonen L. Gene defect in hypodontia: exclusion of EGF, EGFR, and FGF-3 as candidate genes. J Dent Res. 1996;75(6):1346-1352.

2. Breeze J, Dover MS, Williams RW. Contemporary surgical management of hypodontia. Br J Oral Maxillofac Surg. 2017;55(5):454-460.

3. Hu JC, Simmer JP. Developmental biology and genetics of dental malformations. Orthod Craniofac Res. 2007;10(2):45-52.

4. Matalova E, Fleischmannova J, Sharpe PT, Tucker AS. Tooth agenesis: from molecular genetics to molecular dentistry. J Dent Res. 2008;87(7):617-623.

5. Cobourne MT. Familial human hypodontia-is it all in the genes? $\mathrm{Br}$ Dent J. 2007;203(4):203-208.

6. Thesleff I. Genetic basis of tooth development and dental defects. Acta Odontol Scand. 2000;58(5):191-194.

7. Jernvall J, Thesleff I. Reiterative signaling and patterning during mammalian tooth morphogenesis. Mech Dev. 2000;92(1):19-29.

8. Underhill DA. Genetic and biochemical diversity in the Pax gene family. Biochem Cell Biol. 2000;78(5):629-638.

9. das P, Hai M, Elcock C, et al. Novel missense mutations and a 288-bp exonic insertion in PAX9 in families with autosomal dominant hypodontia. Am J Med Genet A. 2003;118A(1):35-42.

10. das P, Stockton DW, Bauer C, et al. Haploinsufficiency of PAX9 is associated with autosomal dominant hypodontia. Hum Genet. 2002;110(4):371-376.

11. Mensah JK, Ogawa T, Kapadia H, Cavender AC, D’Souza RN. Functional analysis of a mutation in PAX9 associated with familial tooth agenesis in humans. J Biol Chem. 2004;279(7):5924-5933.

12. Stockton DW, das P, Goldenberg M, D'Souza RN, Patel PI. Mutation of PAX9 is associated with oligodontia. Nat Genet. 2000;24(1):18-19.

13. Peres RC, Scarel-Caminaga RM, do Espírito Santo AR, Line SR. Association between PAX-9 promoter polymorphisms and hypodontia in humans. Arch Oral Biol. 2005;50(10):861-871.

14. Bianchi FJ, de Oliveira TF, Saito CB, Peres RC, Line SR. Association between polymorphism in the promoter region (G/C-915) of PAX9 gene and third molar agenesis. J Appl Oral Sci. 2007;15(5):382-386.

15. Dahl E, Koseki H, Balling R. Pax genes and organogenesis. Bioessays. 1997;19(9):755-765.

16. Kapadia H, Mues G, D'Souza R. Genes affecting tooth morphogenesis. Orthod Craniofac Res. 2007;10(4):237-244.
17. Peters H, Neubüser A, Balling R. Pax genes and organogenesis: Pax 9 meets tooth development. Eur J Oral Sci. 1998;106 (Suppl 1):38-43.

18. Ogawa T, Kapadia H, Feng JQ, Raghow R, Peters H, D’Souza RN. Functional consequences of interactions between Pax9 and Msx1 genes in normal and abnormal tooth development. J Biol Chem. 2006;281(27):18363-18369.

19. Ogawa T, Kapadia H, Wang B, D'Souza RN. Studies on Pax9-Msx1 protein interactions. Arch Oral Biol. 2005;50(2):141-145.

20. Isman E, Nergiz S, Acar H, Sari Z. PAX9 polymorphisms and susceptibility with sporadic tooth agenesis in Turkish populations: a case-control study. BMC Genomics. 2013;14:733.

21. Mostowska A, Biedziak B, Trzeciak WH. A novel mutation in PAX9 causes familial form of molar oligodontia. Eur J Hum Genet. 2006;14(2):173-179.

22. Frazier-Bowers SA, Scott MR, Cavender A, Mensah J, D’Souza RN. Mutational analysis of families affected with molar oligodontia. Connect Tissue Res. 2002;43(2-3):296-300.

23. Jumlongras D, Lin JY, Chapra A, et al. A novel missense mutation in the paired domain of PAX9 causes non-syndromic oligodontia. Hum Genet. 2004;114(3):242-249.

24. Klein ML, Nieminen P, Lammi L, Niebuhr E, Kreiborg S. Novel mutation of the initiation codon of PAX9 causes oligodontia. J Dent Res. 2005;84(1):43-47.

25. Kobielak A, Kobielak K, Wiśniewski AS, Mostowska A, Biedziak B, Trzeciak WH. The novel polymorphic variants within the paired box of the PAX9 gene are associated with selective tooth agenesis. Folia Histochem Cytobiol. 2001;39(2):111-112.

26. Lammi L, Halonen K, Pirinen S, Thesleff I, Arte S, Nieminen P. A missense mutation in PAX9 in a family with distinct phenotype of oligodontia. Eur J Hum Genet. 2003;11(11):866-871.

27. Zhao J, Hu Q, Chen Y, Luo S, Bao L, Xu Y. A novel missense mutation in the paired domain of human PAX9 causes oligodontia. Am J Med Genet A. 2007;143A(21):2592-2597.

28. Hansen L, Kreiborg S, Jarlov H, Niebuhr E, Eiberg H. A novel nonsense mutation in PAX9 is associated with marked variability in number of missing teeth. Eur J Oral Sci. 2007;115(4):330-333.

29. Nieminen P, Arte S, Tanner D, et al. Identification of a nonsense mutation in the PAX9 gene in molar oligodontia. Eur J Hum Genet. 2001;9(10):743-746.

30. Tallón-Walton V, Manzanares-Céspedes MC, Arte S, et al. Identification of a novel mutation in the PAX9 gene in a family affected by oligodontia and other dental anomalies. Eur J Oral Sci. 2007;115(6):427-432.

31. Mitsui SN, Yasue A, Masuda K, et al. Novel PAX9 mutations cause non-syndromic tooth agenesis. J Dent Res. 2014;93(3):245-249.

32. Shahid M, Balto HA, Al-Hammad N, et al. Mutations in MSX1, PAX9 and MMP20 genes in Saudi Arabian patients with tooth agenesis. Eur J Med Genet. 2016;59(8):377-385.

33. Liang J, Qin C, Yue H, He H, Bian Z. A novel initiation codon mutation of PAX9 in a family with oligodontia. Arch Oral Biol. 2016;61:144-148.
The Application of Clinical Genetics

\section{Publish your work in this journal}

The Application of Clinical Genetics is an international, peer-reviewed open access journal that welcomes laboratory and clinical findings in the field of human genetics. Specific topics include: Population genetics; Functional genetics; Natural history of genetic disease; Management of genetic disease; Mechanisms of genetic disease; Counselling and ethical issues; Animal models; Pharmacogenetics; Prenatal diagnosis; Dysmorphology. The manuscript management system is completely online and includes a very quick and fair peer-review system, which is all easy to use. Visit http://www.dovepress.com/testimonials.php to read real quotes from published authors. 